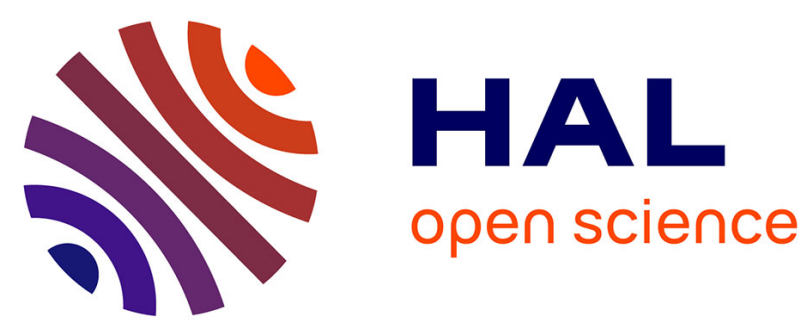

\title{
Clinical characteristics of familial hypocalciuric hypercalcaemia type 1: A multicentre study of 77 adult patients
}

\author{
Céline Mouly, Rosa Vargas-poussou, Anne Lienhardt, Caroline Silve, \\ Marguerite Hureaux, Corinne Magdelaine, Alexandre Buffet, Solange \\ Grunenwald, Jean-Marc Kuhn, Thierry Brue, et al.
}

\section{To cite this version:}

Céline Mouly, Rosa Vargas-poussou, Anne Lienhardt, Caroline Silve, Marguerite Hureaux, et al.. Clinical characteristics of familial hypocalciuric hypercalcaemia type 1: A multicentre study of 77 adult patients. Clinical Endocrinology, 2020, 93 (3), pp.248-260. 10.1111/cen.14211 . hal-03225585

\section{HAL Id: hal-03225585 \\ https: / / hal-amu.archives-ouvertes.fr/hal-03225585}

Submitted on 12 May 2021

HAL is a multi-disciplinary open access archive for the deposit and dissemination of scientific research documents, whether they are published or not. The documents may come from teaching and research institutions in France or abroad, or from public or private research centers.
L'archive ouverte pluridisciplinaire HAL, est destinée au dépôt et à la diffusion de documents scientifiques de niveau recherche, publiés ou non, émanant des établissements d'enseignement et de recherche français ou étrangers, des laboratoires publics ou privés. 


\title{
Clinical characteristics of familial hypocalciuric hypercalcaemia type 1: A multicentre study of 77 adult patients
}

\author{
Céline Mouly $^{1}$ (D) | Rosa Vargas-Poussou ${ }^{2}$ (D) | Anne Lienhardt ${ }^{3}$ | Caroline Silve $^{4}$ | \\ Marguerite Hureaux $^{2}$ | Corinne Magdelaine ${ }^{5}$ | Alexandre Buffet ${ }^{1}$ | \\ Solange Grunenwald ${ }^{1}$ | Jean-Marc Kuhn ${ }^{6}$ | Thierry Brue ${ }^{7}$ | \\ Yves Reznik $^{8}$ | Antoine Tabarin ${ }^{9}$ (D) | Dominique Martin-Coignard ${ }^{10}$ | \\ Jean-Philippe Haymann ${ }^{11}$ | Ivan Tack ${ }^{12}$ | Antoine Bennet ${ }^{1}$ | Philippe Caron ${ }^{1}$ (D) | \\ Agnès Linglart $^{13}$ | Delphine Vezzosi ${ }^{1}$ (D) | for the Reference Centre for Rare Diseases of \\ Calcium, Phosphate Metabolism
}

${ }^{1}$ Department of Endocrinology, Larrey Hospital, CardioMet Institute, University Hospital Centre of Toulouse, Toulouse,

France

${ }^{2}$ Department of Genetics, European Hospital Georges Pompidou, Paris, France

${ }^{3}$ Department of Medical Paediatrics, University Hospital Centre of Limoges, Limoges, France

${ }^{4}$ Department of Molecular Biochemistry and Genetics, Cochin Hospital, Paris, France

${ }^{5}$ Department of Molecular Genetic

Biochemistry, University Hospital Centre of Limoges, Limoges, France

${ }^{6}$ Department of Endocrinology, Diabetes and Metabolic Diseases, University Hospital Centre of Rouen, Rouen, France

${ }^{7}$ Department of Endocrinology, Diabetes and Metabolic Disorders, University Hospital Centre of Marseille, Marseille, France

${ }^{8}$ Department of Endocrinology-Diabetology, University Hospital Centre of Caen, Caen,

France

${ }^{9}$ Department of Endocrinology, Diabetology, Metabolic Diseases and Nutrition, University Hospital Centre of Bordeaux, Bordeaux, France

${ }^{10}$ Medical Genetics and Cytogenetics Laboratory, Hospital Centre of Le Mans, Le Mans, France

${ }^{11}$ Department of Multidisciplinary Function Tests, Tenon Hospital, Paris, France

${ }^{12}$ Department of Physiological Function Tests, University Hospital Centre of Toulouse, Toulouse, France

${ }^{13}$ Department of Paediatric Endocrinology,

\begin{abstract}
Objective: Familial hypocalciuric hypercalcaemia type 1 (FHH1), related to heterozygous loss-of-function mutations of the calcium-sensing receptor gene, is the main differential diagnosis for primary hyperparathyroidism. The aim of our study was to describe clinical characteristics of adult patients living in France with a genetically confirmed FHH1.
\end{abstract}

Design and patients: This observational, retrospective, multicentre study included 77 adults, followed up in 32 clinical departments in France, with a genetic FHH1 diagnosis between 2001 and 2012.

Results: Hypercalcaemia was diagnosed at a median age of 53 years [IQR: 38-61]. The diagnosis was made after clinical manifestations, routine analysis or familial screening in 56, 34 and $10 \%$ of cases, respectively, ( $n=58$; data not available for 19 patients). Chondrocalcinosis was present in $11 / 51$ patients (22\%), bone fractures in $8 / 56(14 \%)$ and renal colic in 6/55 (11\%). The median serum calcium was $2.74 \mathrm{mmol} / \mathrm{L}$ [IQR: 2.63-2.86 mmol/L], the median plasma parathyroid hormone level was $4.9 \mathrm{pmol} / \mathrm{L}$ [3.1-7.1], and the median 24-hour urinary calcium excretion was $2.8 \mathrm{mmol} / 24$ hours [IQR: 1.9-4.0]. Osteoporosis (dual X-ray absorptiometry) or kidney stones (renal ultrasonography) were found in 6/38 patients (16\%) and 9/32 patients (28\%), respectively. Fourteen patients (18\%) underwent parathyroid surgery; parathyroid adenoma was found in three patients (21\%) and parathyroid hyperplasia in nine patients (64\%). No correlation between genotype and phenotype was established.

Conclusion: This large cohort study demonstrates that FHH1 clinical characteristics can be atypical in 33 patients (43\%). Clinicians should be aware of this rare differential diagnosis in order to adopt an appropriate treatment strategy. 
Diabetology and Severe Obesity, Bicêtre Hospital, Paris, France

\section{Correspondance}

Delphine Vezzosi, Service d'Endocrinologie, maladies métaboliques et nutrition, Hôpital

Larrey, 24, chemin de Pouvourville - TSA

30030, 31059 Toulouse cedex 9, France.

Email: vezzosi.d@chu-toulouse.fr

\section{KEYWORDS}

calcium-sensing receptor, familial hypocalciuric hypercalcaemia, parathyroid adenoma, primary hyperparathyroidism

\section{1 | INTRODUCTION}

In a patient given a biochemical diagnosis of primary hyperparathyroidism (PHPT), familial hypocalciuric hypercalcaemia (FHH), albeit rare, should always be considered in the differential diagnosis. $\mathrm{FHH}$, inherited as an autosomal dominant trait, was first described by Foley in $1972^{1}$ and is characterized by a slightly elevated serum calcium, with inappropriate plasma parathyroid hormone (PTH) mostly in the reference range, very low 24-hour urinary calcium excretion and the absence of clinical morbidities such as osteoporosis or kidney stones. In $65 \%$ of patients, $\mathrm{FHH}$ is due to heterozygous inactivating mutation in the gene encoding the calcium-sensing receptor (CaSR), leading to type $1 \mathrm{FHH}$ (FHH1, OMIM\#145980). ${ }^{2}$ Although parathyroidectomy is considered as a first-line treatment in PHPT, surgery is ineffective in $\mathrm{FHH}$. Therefore, the correct diagnosis is important in order to avoid ineffective or even deleterious surgical management strategies. The calcium/creatinine clearance ratio (CCCR) has been put forward to differentiate the two entities, but an overlap is observed, especially for values between 0.01 and $0.02 .^{3}$ Thus, a risk equation has recently been developed in an attempt to distinguish between these two entities. ${ }^{4}$

Atypical characteristics including chondrocalcinosis, kidney stones or very high levels of PTH or serum calcium ${ }^{5,6}$ were described in some patients. These overlaps could complicate differential diagnosis between these two conditions in the clinical setting. Moreover, parathyroid adenomas have been reported in patients with CASR inactivating mutation (Table 1).

The aim of this study was to describe the clinical characteristics in a large cohort of French adult patients with genetically confirmed $\mathrm{FHH} 1$.

\section{2 | PATIENTS AND METHODS}

\section{1 | Design}

Between 2001 and 2012, all patients over 18 years of age with CASR inactivating mutation diagnosed in 3 French centres performing CASR genotyping were considered for inclusion in this observational, retrospective, multicentre study.

This study was conducted in accordance with the Declaration of Helsinki and approved by the local Ethics Committees of Toulouse University Hospital (authorization number 24-0413, granted on 6 May 2014) and by the Commission Nationale de I'Informatique et des Libertés (French Data Protection Authority) (CNIL DR-2014-343). In accordance with French legislation, all patients gave their informed consent to undergo genetic testing.

\section{2 | Patients}

One hundred and sixty-four records of patients aged 18 years or more at the time of the genetic diagnosis of CASR inactivating mutation were included in this study. The patients' files were retrospectively reviewed by one investigator (CM). Eighty-four patients were excluded: 45 patients because of absence of response from their medical centres and 39 patients due to insufficient data in patients' files. Data were collected for 80 patients (48\% of the initial population), followed up in 32 French Endocrinology, Nephrology or Rheumatology departments. Finally, three patients were excluded due to uncertain significance of the genetic variant that was found.

\section{3 | Methods}

The following data were recorded: circumstances under which hypercalcaemia was diagnosed, clinical symptoms, evaluation of renal and/or bone characteristics, laboratory results, parathyroid imaging and neck surgery results.

Biochemistry: The following data were collected: total and ionized calcium, albumin, protein, creatinine, phosphate, PTH, calcidiol, calcitriol, magnesium plasma levels and 24-hour urinary calcium, creatinine and phosphate excretion measured by standard laboratory methods used in each centre. We adjusted total serum calcium for individual variations in serum albumin or in proteins. The albumin-adjusted calcium concentration was calculated as adjusted calcaemia $(\mathrm{mmol} / \mathrm{L})=$ total calcaemia $(\mathrm{mmol} / \mathrm{L})-$ $0.025 \times$ (plasma albumin (g/L) - 40). The adjusted calcium protein level was calculated as follows: adjusted calcaemia $(\mathrm{mmol} / \mathrm{L})=$ total calcaemia $(\mathrm{mmol} / \mathrm{L}) /(0.55 \times$ (plasma protid $(\mathrm{g} / \mathrm{L}) / 160)$. Creatinine clearance was calculated using the MDRD (Modification of Diet in Renal Disease) formula. The calcium to creatinine clearance ratio was calculated by multiplying the urine calcium/creatinine ratio by the serum creatinine/calcium ratio. For each item of data, we selected the results, which were the closest to the time of diagnosis of the hypercalcaemia.

Dual-energy $X$-ray absorptiometry (DXA): bone mass density $T$ score and $Z$ score (measured with equipment from each centre) were 
TABLE 1 Patients with FHH1 presenting a histologically confirmed parathyroid adenoma, reported in literature and in our study

\begin{tabular}{|c|c|c|c|c|c|c|c|}
\hline & 1 & 2 & 3 & 4 & 5 & 6 & 7 \\
\hline Sex & $\mathrm{F}$ & M & $\mathrm{F}$ & $\mathrm{F}$ & $\mathrm{F}$ & M & $\mathrm{F}$ \\
\hline Age at hypercalcaemia & 63 & 61 & 76 & 75 & 20 & 76 & 45 \\
\hline Genotype & R220P & $\mathrm{R} 25 \mathrm{X}$ & E250K & E250K & Q926R & $\begin{array}{l}\text { p.(Ser1065 } \\
\text { Valfs*11) }\end{array}$ & C562Y \\
\hline Reference & $\begin{array}{l}\text { Egan et al, } \\
2013^{22}\end{array}$ & $\begin{array}{l}\text { Frank-Raue } \\
\text { et al, } 2011^{21}\end{array}$ & $\begin{array}{l}\text { Frank-Raue et al, } \\
2011^{21}\end{array}$ & $\begin{array}{l}\text { Frank-Raue } \\
\text { et al, } 2011^{21}\end{array}$ & $\begin{array}{l}\text { Frank-Raue } \\
\text { et al, } 2011^{21}\end{array}$ & $\begin{array}{l}\text { Yabuta et al, } \\
2009^{23}\end{array}$ & Burski et al $2002^{24}$ \\
\hline $\begin{array}{l}\text { Symptomatology or } \\
\text { Comorbidities at } \\
\text { diagnosis }\end{array}$ & $\begin{array}{l}\text { - Nephro- } \\
\text { lithiasis (at } \\
33 \text { years) } \\
\text { - Osteopaenia } \\
\text { - Chronic } \\
\text { constipation }\end{array}$ & $\begin{array}{l}\text { - Nephro- } \\
\text { lithiasis } \\
\text { - HBP }\end{array}$ & $\begin{array}{l}\text { - Nephro- } \\
\text { lithiasis } \\
\text { - HBP } \\
\text { - Osteoporosis } \\
\text { (vertebral } \\
\text { fractures) }\end{array}$ & $=0$ & HBP & $\begin{array}{l}\text { - Nephro- } \\
\text { lithiasis }\end{array}$ & $\begin{array}{l}\text { - Constipation } \\
\text { - Fatigue } \\
\text { - PUPDS } \\
\text { - Psychiatric } \\
\text { disorder } \\
\text { (personality } \\
\text { trouble, } \\
\text { depression) } \\
\text { - Gastric ulcer } \\
\text { - HBP }\end{array}$ \\
\hline \multicolumn{8}{|c|}{ Results before parathyroid surgery } \\
\hline $\mathrm{Ca}(\mathrm{mmol} / \mathrm{L})$ & 3.25 & 2.90 & 2.90 & 3.0 & 3.3 & 2.80 & 4.48 \\
\hline PTH (pmol/L) & 15 & 9 & 17 & 43 & 21 & 14 & 63 \\
\hline $\mathrm{Ca} \cup(\mathrm{mmol} / 24 \mathrm{~h})$ & 4.8 & NA & NA & NA & NA & NA & NA \\
\hline $\mathrm{CCCR}$ & NA & 0.031 & 0.031 & 0.025 & 0.027 & 0.005 & 0.008 \\
\hline $\begin{array}{l}\text { Cervical } \\
\text { morphologic } \\
\text { examinations }\end{array}$ & $\mathrm{MIBI}+$ & $\begin{array}{l}\text { US and/or } \\
\mathrm{MIBI}+\end{array}$ & $\begin{array}{l}\text { US } \\
\text { and/or MIBI + }\end{array}$ & $\begin{array}{l}\text { US and/or } \\
\mathrm{MIBI}+\end{array}$ & $\begin{array}{l}\text { US and/or } \\
\mathrm{MIBI}+\end{array}$ & $\begin{array}{l}\text { US, MIBI, } \\
\text { cervical } \\
\text { scanner + }\end{array}$ & $\begin{array}{l}\text { US- } \\
\mathrm{MIBI}+\end{array}$ \\
\hline $\begin{array}{l}\text { Age at parathyroid } \\
\text { surgery }\end{array}$ & 71 & NA & NA & NA & 23 & 76 & NA \\
\hline \multicolumn{8}{|c|}{ Results after parathyroid surgery } \\
\hline $\begin{array}{l}\text { Follow-up of } \\
\text { symptoms after } \\
\text { parathyroid } \\
\text { surgery }\end{array}$ & $\begin{array}{l}\text { Fatigue and } \\
\text { psychiatric } \\
\text { troubles } \\
\text { improved }\end{array}$ & NA & NA & NA & NA & NA & NA \\
\hline $\mathrm{Ca}(\mathrm{mmol} / \mathrm{L})$ & 2.79 & 2.90 & 2.30 & 2.20 & 2.30 & 2.68 & 2.72 \\
\hline $\begin{array}{l}\text { PTH after surgery } \\
(\mathrm{pg} / \mathrm{mL})\end{array}$ & 68 & 40 & 40 & 63 & 41 & 54 & 73 \\
\hline $\mathrm{Ca} \cup(\mathrm{mmol} / 24 \mathrm{~h})$ & 2.2 & 1.8 & 0.3 & NA & NA & NA & NA \\
\hline CCCR & 0.008 & 0.004 & 0.009 & NA & 0.015 & 0.004 & 0.002 \\
\hline
\end{tabular}

Note: Normal reference ranges in present study: Total serum calcium: 2.2-2.6 mmol/L; PTH: 1.1-6.8 pmol/L; 24-h urinary calcium excretion: 2.5-7 mmol/24 h

Abbreviations: Ca U: 24-hour urinary calcium excretion; Ca: total serum calcium; CCCR: calcium creatinine clearance ratio (urinary calcium/plasma calcium x plasma creatinine/urinary creatinine); F: female; HBP: high blood pressure; M: male; PUPDS: polyuro-polydipsic syndrome; US: ultrasonography.

measured at three sites: lumbar (L2-L4 or L1-L4), femoral and radial; if these data were not available, osteoporosis or bone demineralzsation reported in the medical record was taken into account. Osteoporosis was defined by a T score below $-2.5 \mathrm{SD}$, and osteopaenia by a T score between -1 and -2.5 SD, in men and women over 50 years of age. In men and women under 50 years of age, bone demineralization was defined by a $Z$ score below -2 SD.

Genetics: Genomic DNA was isolated from white blood cells using standard procedures. Coding exons 2-7 and the immediate flanking intron sequence were amplified and sequenced bidirectionally as previously described. , $^{4,8}$ Sequences were aligned to the GenBank CASR reference sequence NM_000388.3. Variants not described in the HGMD database http://www.hgmd.cf.ac.uk/ac/ gene.php?gene=CASR were classified using the American College of Medical Genetics (ACMG) Guidelines. ${ }^{9}$ The ACMG recommendations to classify sequence variants is the method used worldwide to interpret variants in genes responsible for Mendelian disorders in the clinical setting. ACMG recommends the classification of 


\begin{tabular}{|c|c|c|c|c|c|c|c|c|}
\hline 8 & 9 & 10 & 11 & 12 & 13 & 14 & 15 & 16 \\
\hline M & $\mathrm{F}$ & $M$ & $\mathrm{~F}$ & $M$ & $\mathrm{~F}$ & $\mathrm{~F}$ & M & $\mathrm{F}$ \\
\hline 16 & NA & 57 & 56 & 35 & 56 & 35 & 72 & 15 \\
\hline $\begin{array}{l}\text { Brachet et al, } \\
2009^{25}\end{array}$ & $\begin{array}{l}\text { Brachet } \\
\text { et al, } \\
2009^{25}\end{array}$ & $\begin{array}{l}\text { Forde et al, } \\
2014^{26}\end{array}$ & $\begin{array}{l}\text { Eldeiry et al, } \\
2012^{27}\end{array}$ & $\begin{array}{l}\text { Eldeiry et al, } \\
2012^{27}\end{array}$ & $\begin{array}{l}\text { Guarnieri et al, } \\
2010^{18}\end{array}$ & Present study & $\begin{array}{l}\text { Present } \\
\text { study }\end{array}$ & $\begin{array}{l}\text { Present } \\
\text { study }\end{array}$ \\
\hline $\begin{array}{l}\text { - Fatigue } \\
\text { - Abdominal } \\
\text { pain } \\
\text { - PUPDS }\end{array}$ & & $\begin{array}{l}\text { - } \text { Fatigue } \\
\text { - Joint } \\
\text { pain } \\
\text { - Insomnia }\end{array}$ & NA & $\begin{array}{l}\text { - Fatigue } \\
\text { - Decreased } \\
\text { tolerance } \\
\text { exercise } \\
\text { - Osteopaenia }\end{array}$ & $\begin{array}{l}\text { - HBP } \\
\text { - Nephro- } \\
\text { lithiasis (at } \\
36 \text { years) } \\
\text { - Osteoporosis } \\
\text { without } \\
\text { fracture }\end{array}$ & $\begin{array}{l}\text { - Digestive } \\
\text { troubles } \\
\text { - Bone } \\
\text { demineralization }\end{array}$ & $\begin{array}{l}\text { - } \text { Fatigue } \\
\text { - Digestive } \\
\text { troubles } \\
\text { - HBP } \\
\text { - Cognitive } \\
\text { troubles }\end{array}$ & $\begin{array}{l}\text { - Fatigue } \\
\text { - Digestive } \\
\text { troubles }\end{array}$ \\
\hline
\end{tabular}

\begin{tabular}{|c|c|c|c|c|c|c|c|c|}
\hline 3.50 & 3.25 & 2.61 & 2.87 & 2.97 & 2.98 & 3.14 & 3.3 & 3.01 \\
\hline 27 & NA & 9 & 7 & 9 & 15 & 13 & 11 & 3 \\
\hline 0.009 & NA & NA & 0.0047 & 0.0096 & 0.025 & NA & 0.0011 & 0.01 \\
\hline $\begin{array}{l}\text { US- } \\
\text { MIBI + }\end{array}$ & NA & $\begin{array}{l}\text { US + } \\
\text { MIBI + }\end{array}$ & $\begin{array}{l}\text { US + } \\
\text { MIBI + }\end{array}$ & $\begin{array}{l}\text { US + } \\
\text { MIBI + } \\
\text { (possible) }\end{array}$ & US + & $\begin{array}{l}\text { US + } \\
\text { MIBI + }\end{array}$ & $\begin{array}{l}\text { US + } \\
\text { MIBI + }\end{array}$ & MIBI- \\
\hline 16 & 55 & 57 & 56 & 45 & 56 & 36 & 73 & 25 \\
\hline NA & NA & Unchanged & NA & NA & $\begin{array}{l}\text { PUPDS and } \\
\text { psychiatric } \\
\text { troubles } \\
\text { improved }\end{array}$ & NA & $\begin{array}{c}\text { Cognitive } \\
\text { troubles } \\
\text { improved }\end{array}$ & \\
\hline 69 & 74 & 59 & 42 & 47 & NA & 81 & 64 & 32 \\
\hline NA & NA & 2.3 & 2.5 & 1.8 & 2.5 & NA & NA & NA \\
\hline 0.001 & 0.004 & $<0.01$ & 0.0045 & 0.0038 & NA & NA & NA & NA \\
\hline
\end{tabular}

variants into five categories (class 1: benign; class 2: likely benign; class 3: uncertain significance; class 4: likely pathogenic and class 5: pathogenic) based on a combination of several criteria including population data, computational data, functional data and segregation data. Class 4 and 5 variants were required to confirm $\mathrm{FHH}$ diagnosis, using the website: http://www.medschool.umaryland. edu/Genetic_Variant_Interpretation_Tool1.html/. All the variants described in this cohort were carefully revised with the criteria of ACMG classification.
Statistics: Results were reported as medians and interquartile ranges (IQR). Qualitative values were compared using Fisher's exact test; quantitative values were compared between 2 groups using the Mann-Whitney test for unmatched data and Wilcoxon's test for matched data; quantitative values were compared between 3 groups using the Kruskal-Wallis test. Dependence between quantitative variables was analysed with Spearman's rho correlation coefficient ( $r$ ). Statistical analyses were carried out using GraphPad version 5 software for Windows (La Jolla 
California USA). The $P$-value was two-sided and the cut-off value of significance was .05 .

\section{3 | RESULTS}

\section{1 | Clinical characteristics}

Seventy-seven patients were enrolled including 49 females (64\%). The median age at diagnosis of hypercalcaemia was 53 years (IQR: 38-61; range: 15-76 years). The main diagnostic circumstances are summarized in Figure 1. Hypercalcaemia was detected during a routine check-up or fatigue investigation in $20 / 58$ patients (34\%; data not available for 19 patients) (Figure 1). A familial history of hypercalcaemia, PHPT or neck surgery was documented in $32 / 56$ patients (57\%) on diagnosis, with one family member presenting $\mathrm{FHH}$ in 6/56 cases (11\%) (Figure 2).

\subsection{Kidney, bone and other comorbidities}

Six patients had a history of renal colic. Their 24-hour urinary calcium excretion (median $3 \mathrm{mmol} / 24 \mathrm{~h}$; IQR: 2.36-3.37) did not differ significantly from those recorded in patients without history of renal colic (median $2.80 \mathrm{mmol} / 24 \mathrm{~h}$; IQR: 1.79-4.30; $P=1.00$ ). Kidney stones were found in 9 out of 32 patients $(28 \%)$ who had a renal ultrasonography; they were bilateral in 5 out of nine patients; no nephrocalcinosis was detected; three of these patients had been symptomatic with an episode of renal colic.

Osteoporosis was diagnosed in six female patients; 3 of them were between 62 and 72 years of age at the time of diagnosis (no data available for the other three patients). In 38 patients who underwent DXA (median age: 58 years; 12 males and 26 females; 10 patients below 50 years of age), the median $Z$ score was 0.20 SD (IQR: $-0.85-1.06)$ in the lumbar spine $(n=20),-0.15 S D(I Q R$ : $-0.43-0.53)$ in the femoral neck $(n=20)$ and -0.85 SD (IQR: -1.48 - -0.11$)$ at the one-third distal radius site $(n=8)$. Bone characteristics at DXA showed an osteoporosis in 6/35 patients (17\%), an osteopaenia ( $T$ score between -1 and $-2.5 \mathrm{SD}$ at age $>50$ years) in $11 / 35$ (31\%) and a low bone mineral density at age $<50$ years ( $Z$ score < -2SD) in 2/35 (6\%). Eight out of 56 patients sustained a fracture (14\%); 2 of these patients were suspected to have been osteoporotic (vertebral and femoral neck) before the age of 55 . There were no significant clinical or laboratory differences between osteoporotic patients and nonosteoporotic patients, except for the age at which hypercalcaemia was diagnosed (63 years; IQR: 56-65 for osteoporotic patients, vs. 45 years; IQR: 39-56 for nonosteoporotic patients; $P=.039$ ).

Other comorbidities were chondrocalcinosis ( $n=11 / 51 ; 22 \%$ ), psychiatric disease $(n=18 / 55 ; 33 \%$ ) and hypertension ( $n=29 / 57$; $51 \%)$. The prevalence of these comorbidities in our study is higher than the prevalence observed in the general population.

\section{3 | Laboratory characteristics}

A median maximum serum calcium of $2.88 \mathrm{mmol} / \mathrm{L}$ (IQR: 2.78 3.00 ) and a median minimum serum calcium of $2.59 \mathrm{mmol} / \mathrm{L}$ (IQR: 2.52-2.71) were recorded (normal range: $2.20-2.60$ ). There was a significant correlation between the minimum and maximum serum calcium for the same patient (rho: 0.52; p: 0.0001). The serum total calcium level was above $2.9 \mathrm{mmol} / \mathrm{L}$ in $11 / 77$ patients (14\%) (Table 2).

Plasma PTH was above $10.6 \mathrm{pmol} / \mathrm{L}(100 \mathrm{pg} / \mathrm{mL})$ in $6 / 66$ patients (9\%) (normal range: 1.1-6.8).

Twenty-four-hour urinary calcium excretion was elevated (>0.1 mmol $/ \mathrm{kg} / 24 \mathrm{~h}$ ) in 4/42 patients (10\%) (Table 2). The CCCR was below 0.01 in $15 / 30$ patients (50\%) and above 0.02 in $3 / 30$ patients (10\%).

There was no correlation between laboratory characteristics and gender or age, except for a weak correlation between age and PTH ( $r$ ho $=0.33 ; P=.015$ ). Serum calcium did not differ statistically between patients with or without comorbidities.

\section{4 | Morphological characteristics and therapeutic management}

Neck ultrasonography and MIBI scintigraphy were performed in 42 and 39 patients, respectively. Neck ultrasonography led to the localization of one (or more) enlarged parathyroid gland(s) in $24 \%$ of patients ( $n=10 / 42$ ), and MIBI scintigraphy led to the detection of one (or more) pathological hyperfixation in $26 \%$ of patients ( $n=10 / 39$ ).

Thirteen out of 77 patients (17\%) received a medical treatment with cinacalcet. With a median dose of $45 \mathrm{mg} /$ day [IQR: 30-60], it led to a median serum calcium reduction of $0.44 \mathrm{mmol} / \mathrm{L}$ [IQR: $0.31-$ $0.55]$ after 2 to 6 months treatment and to a normalization of serum calcium in 7 out of nine patients with available data.

Surgery was performed in 14/77 patients (18\%): 1 to 3.5 parathyroid glands per patient were removed. Twenty-nine glands were analysed histologically: 10 were normal (34\%), 16 were hyperplastic (55\%), and 3 were adenomatous (10\%). Surgery was performed prior to genetic diagnosis in every patient except one; genetic diagnosis was obtained within a median period of 12 months [IQR: 3-40] after surgery. Surgery had been performed because of increased serum calcium above $2.80 \mathrm{mmol} / \mathrm{L}$ in 11 out of 14 patients with available data (and $>3 \mathrm{mmol} / \mathrm{L}$ in 4 of them). Moreover, two patients presented with bone comorbidities (osteoporosis and/or osteoporotic fractures), one patient presented with cognitive disorders, two patients presented with renal comorbidities (kidney stones and/or history of renal colic), two patients presented with chondrocalcinosis and one patient had undergone one episode of acute pancreatitis at the age of 24 years (Table 3). Morphological examinations did not predict the presence of a histologically abnormal parathyroid gland. One of the morphological examinations performed found one abnormal parathyroid gland in the two patients with four histologically normal parathyroid glands. On the contrary, the morphological 
FIGURE 1 Circumstances leading to diagnosis of hypercalcaemia (data available for 58 patients)
FIGURE 2 Family history (data available for 56 patients). (* Fracture considered: fracture whose site suggests osteoporosis). $\mathrm{FHH}$ : familial hypocalciuric hypercalcaemia; PHPT: Primary hyperparathyroidism

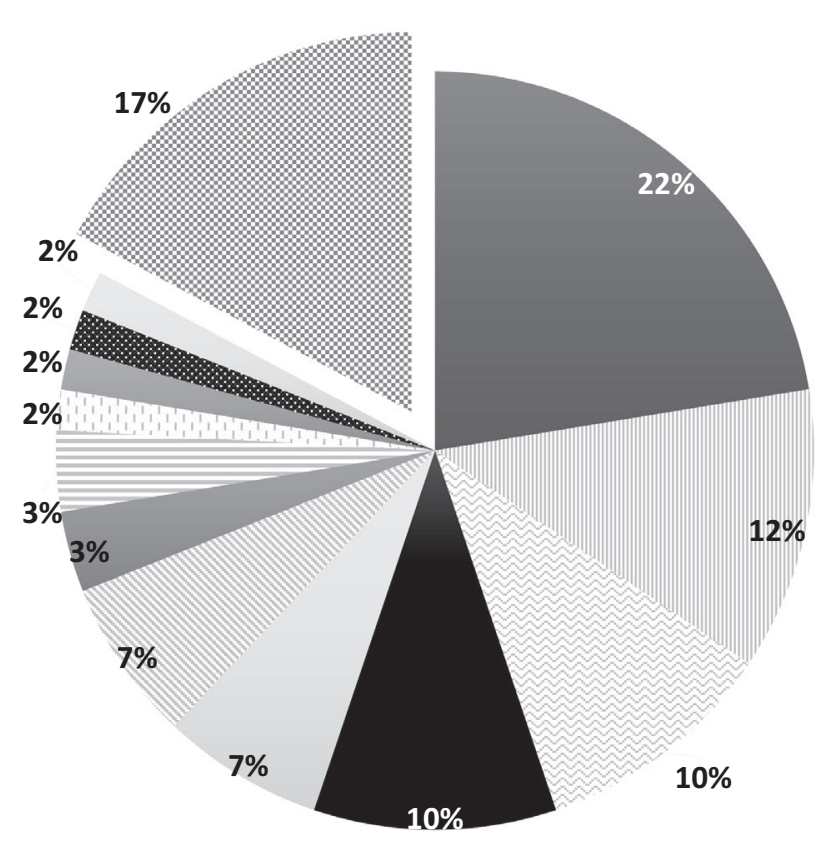

routine analysis

|| fatigue

familial screening

joint pain

faintness

osteoporosis

chondrocalcinosis

$\equiv$ renal colic

fracture

- polyuria/polydipsia

pancreatitis

renal insufficiency

sothers

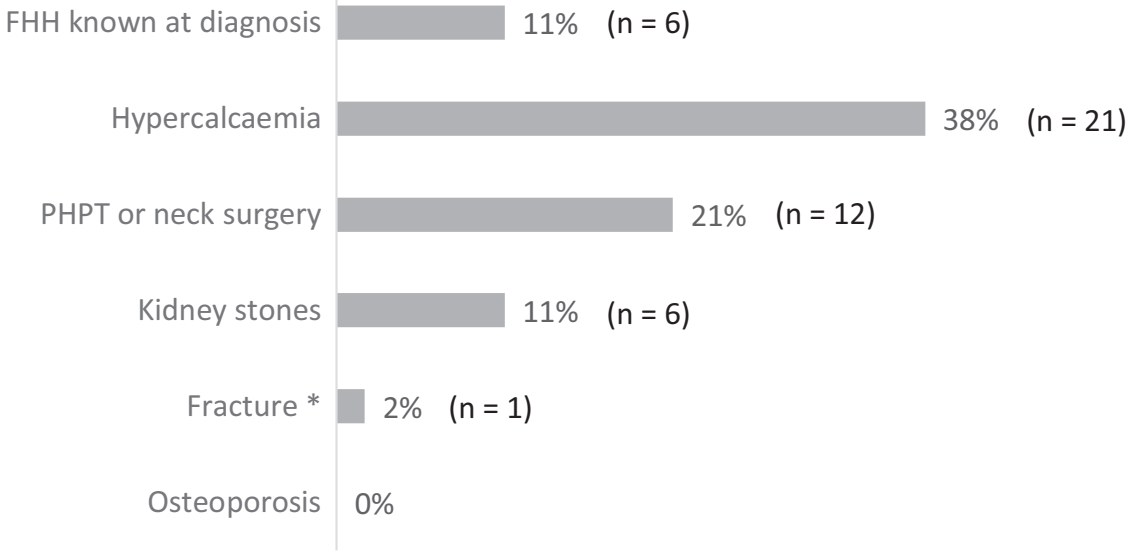

examinations did not detect any abnormal parathyroid gland in 5/11 (45\%) patients with at least one histologically abnormal parathyroid gland. Serum calcium returned to the normal range in two patients after surgery; a parathyroid adenoma was histologically confirmed in these two patients, and the serum calcium was still normal at the last visit, 2 and 10 years after surgery, respectively (Table 1). In five patients, one hyperplastic gland was found (after removal of 1, 2 or 3.5 parathyroid glands). In three patients, 2 or more hyperplastic glands were found (after removal of 2, 3 or 3.5 parathyroid glands). Calcium levels did not return to the normal range in any of these patients.

\subsection{Typical and atypical characteristics of FHH}

In this study, 51/77 patients (66\%) presented with one or more typical criteria of $\mathrm{FHH}$ such as a familial history of hypercalcaemia or parathyroid surgery, and/or a 24-hour urinary calcium excretion below
$3.5 \mathrm{mmol} / 24 \mathrm{~h}$. However, 33/77 patients (43\%) presented with an atypical $\mathrm{FHH}$ characteristic such as hypercalciuria $>7 \mathrm{mmol} / 24 \mathrm{~h}$ or $>0.1 \mathrm{mmol} / \mathrm{kg} / 24 \mathrm{~h}, \mathrm{CCCR}>0.02$, serum calcium $>3 \mathrm{mmol} / \mathrm{L}$, a high PTH level $>10.6 \mathrm{pmol} / \mathrm{L}(100 \mathrm{pg} / \mathrm{mL})$, presence of kidney stones or osteoporotic bone fracture(s), evidence of parathyroid adenoma on neck ultrasonography or MIBI scintigraphy, or a surgically excised parathyroid adenoma.

\section{6 | Genetic characteristics}

The median age at the time of the genetic diagnosis was 57 years (IQR: 42-65). Sixty different mutations were identified in this series; $50 / 60$ (83\%) were missense mutations (Table 4). They were mostly localized in the extracellular domain (35/60; 58\%). Ten (17\%) of these mutations were identified in 2 or more patients (regardless of family connections), without any phenotype-genotype correlation 
TABLE 2 Laboratory characteristics

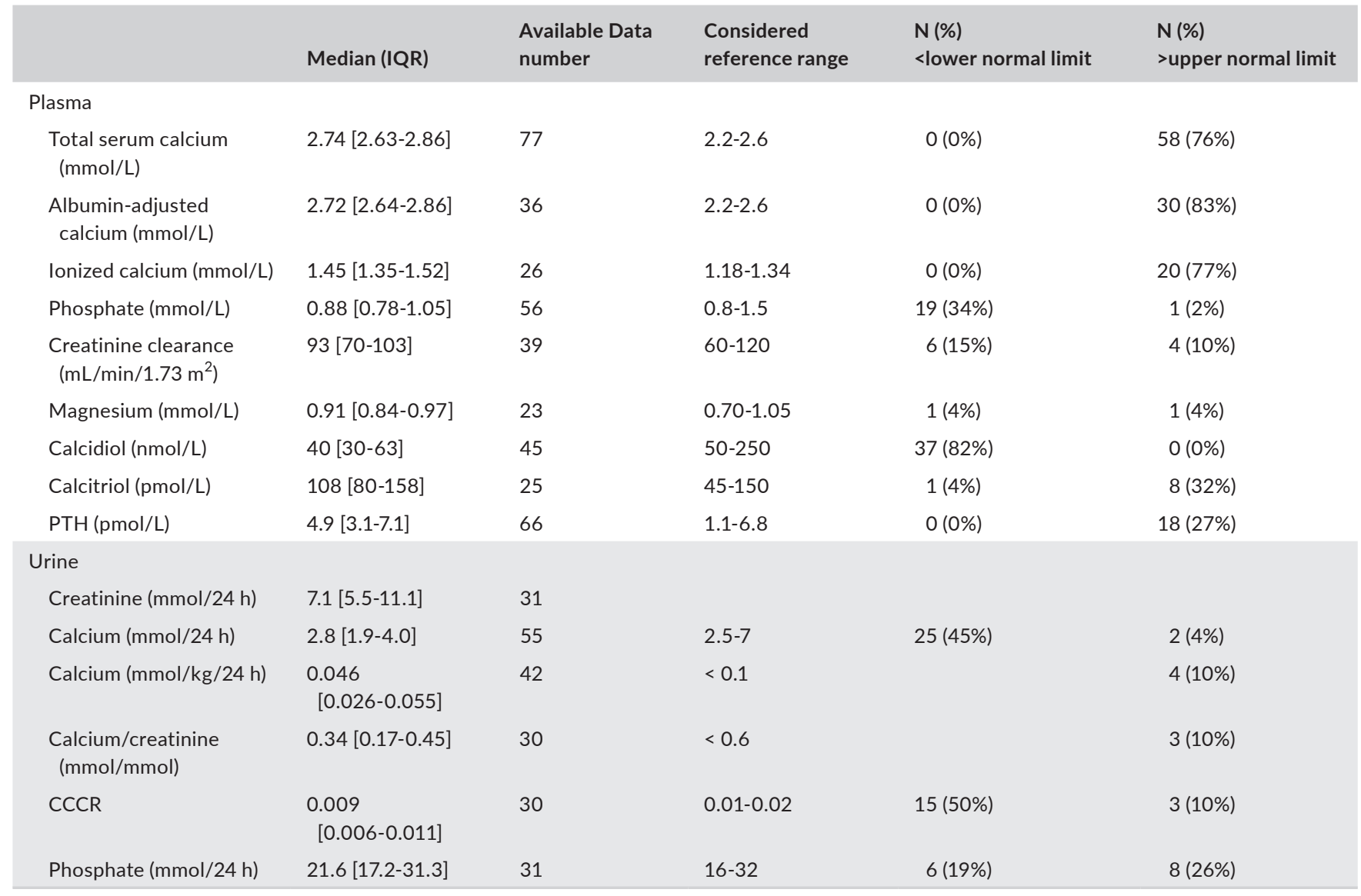

Note: For each variable, the first result during the first 6 mo of follow-up was collected.

Abbreviations: CCCR: calcium creatinine clearance ratio (urinary calcium/plasma calcium x plasma creatinine/urinary creatinine); PTH: parathyroid hormone.

being identified. Actually, 16/60 (16\%) CASR variants had not been yet described and identified in terms of function and 12 of them are missense. All of them were class 4 or class 5 variants.

\section{4 | DISCUSSION}

A large cohort of patients with genetically proven $\mathrm{FHH} 1$ is described in this paper. In this study, 51/77 patients (66\%) presented with one or more typical FHH criteria. However, 33/77 patients (43\%) had atypical $\mathrm{FHH}$ characteristics.

First, in our study, hypercalcaemia is not generally diagnosed at a young age. Indeed, the median age for diagnosis is 53 years; only $10 \%$ of patients were diagnosed through familial screening, and the age at which hypercalcaemia is diagnosed varies according to diagnostic circumstances. Marx et al found that hypercalcaemia was diagnosed at $48 \pm 6.1$ years of age among index cases, ${ }^{10}$ which is similar to the age observed in our cohort, compared to $37 \pm 7$ years in Simonds' cohort. ${ }^{5}$

Secondly, we show that kidney and bone comorbidities are not rare in $\mathrm{FHH}$. In a Danish series of 100 patients with familial hypocalciuric hypercalcaemia (data available for 66 patients), osteoporosis was diagnosed in 6 to $9 \%$ of cases $^{3}$; this prevalence is lower than that recorded in our study, but DXA was performed at a younger age in these patients. In our cohort, the $Z$ score at lumbar and femoral sites indicated a bone mineral density similar to that of the general population at the same age. Another French FHH1 series highlighted a history of kidney stones in 4/52 patients. ${ }^{7}$ In our study, more patients presented with kidney stones on renal ultrasonography (28\%). Clinical or radiological chondrocalcinosis was found to be highly prevalent in our study, which suggests a higher risk of joint impairment. To our knowledge, this has not yet been reported. These data showed that the diagnosis of $\mathrm{FHH}$ cannot be ruled out by comorbidities classically associated with PHPT.

Concerning biological results, some points need to be underlined. 24-hour urinary calcium excretion in $\mathrm{FHH}$ patients could be within the same range as that measured in PHPT patients. In our study, despite a low 24-hour urinary calcium excretion of $2.8 \mathrm{mmol} / 24 \mathrm{~h}$, CCCR ranged from 0.01 to 0.02 in $40 \%$ of patients and was even $>0.02$ in $10 \%$ of cases. CCCR $>0.01$ was reported in 5 to $35 \%$ of patients, based on published data. ${ }^{3,11,12}$

We did not find any correlations between age and serum calcium, which suggests that these levels remain stable on a lifelong basis around an individual set-point. This hypothesis is further evidenced by the correlation found between minimum and maximum serum calcium during follow-up. A plasma magnesium level above the 
TABLE 3 Phenotypic description of patients who underwent a parathyroid surgery

\begin{tabular}{|c|c|}
\hline & $\begin{array}{l}\text { Patients with } \\
\text { parathyroid surgery }\end{array}$ \\
\hline N & 14 \\
\hline Age at hypercalcaemia diagnosis & $49[35-55]$ \\
\hline Age $<50$ years & $N=7 / 13(54 \%)$ \\
\hline Total serum calcium & $2.90[2,84-2,99]$ \\
\hline Serum calcium > $2.80 \mathrm{mmol} / \mathrm{L}$ & $N=11 / 14(79 \%)$ \\
\hline Osteoporosis or osteoporotic fracture & $N=2 / 7(29 \%)$ \\
\hline $\begin{array}{l}\text { Renal colic or kidney stones at } \\
\text { ultrasonography }\end{array}$ & $N=2 / 14(14 \%)$ \\
\hline Chondrocalcinosis & $N=2 / 12(17 \%)$ \\
\hline Cognitive impairment & $N=1 / 13(8 \%)$ \\
\hline Psychiatric disorders & $N=5 / 13(38 \%)$ \\
\hline Acute pancreatitis & $N=1 / 13(8 \%)$ \\
\hline 24-h urinary calcium excretion ( $\mathrm{mmol} / 24 \mathrm{~h}$ ) & $4.1[2.6-5.5]$ \\
\hline $\begin{array}{l}\text { 24-h urinary calcium excretion } \\
>7 \mathrm{mmol} / 24 \mathrm{~h}\end{array}$ & $1 / 11(9 \%)$ \\
\hline \multicolumn{2}{|l|}{ Number of criteria indicative for surgery $\left({ }^{a}\right)$} \\
\hline${ }^{\mathrm{a}} 0$ & $\begin{array}{l}1 \text { (surgery } 7 \text { y before } \\
\text { genetic diagnosis) }\end{array}$ \\
\hline $\mathrm{a}_{1}$ & $5(36 \%)$ \\
\hline${ }^{\mathrm{a}} 2$ & $7(50 \%)$ \\
\hline a 3 & $1(7 \%)$ \\
\hline
\end{tabular}

${ }^{a}$ Criteria for surgery: age $<50 \mathrm{y}$, and/or serum calcium $>2.80 \mathrm{mmol} / \mathrm{L}$, and/or osteoporosis, and/or renal colic or kidney stones at ultrasonography.

normal range is typically described in $\mathrm{FHH} 1 .^{13}$ This was not detected in our patient cohort since magnesium levels were within the normal range in $92 \%$ of patients. A normal plasma magnesium concentration was also observed by Vargas-Poussou et al. ${ }^{7}$

The French series of Vargas-Poussou et al highlighted an important overlap with PHPT in most of the individual laboratory values. ${ }^{7}$ Plasma PTH concentrations were abnormally high in $23 \%$ of $\mathrm{FHH}$ patients. Our results are consistent with these data, with $27 \%$ of patients having high PTH levels, whereas other studies report elevated PTH values in 8 to $24 \%$ of $\mathrm{FHH}$ patients. ${ }^{14-16}$

Surgery is not routinely indicated in $\mathrm{FHH}$ given its ineffectiveness in normalizing calcium levels. This therapeutic choice was made independently by each medical unit. Our results showed that parathyroid surgery for a few patients with total serum calcium $>3 \mathrm{mmol} / \mathrm{L}$ can reduce or even normalize serum calcium, especially if parathyroid adenoma is excised. The association between $\mathrm{FHH} 1$ and parathyroid adenomas is more common than anticipated from a statistical perspective. Prevalence was estimated at $2.9 \%$ in a cohort of 139 patients presenting hypercalcaemia that suggests $\mathrm{PHPT}^{17}$ In our study, the prevalence rate was 3.9\%. Thirteen patients with $\mathrm{FHH}$ who underwent removal of a parathyroid adenoma are described in the literature ${ }^{14,17-23} ; 38 \%$ had a preoperative serum calcium above $3.2 \mathrm{mmol} / \mathrm{L}$ (Table 1 ).
The involvement of CaSR in PHPT pathogenesis is controversial. Nevertheless, casr knockout mice presented with parathyroid hypertrophy. ${ }^{24}$ Moreover, CaSR activation stimulates a MAPK signalling pathway with an inhibitory effect on parathyroid cell proliferation. Therefore, reduced pathway activity could promote the development of an adenoma. ${ }^{25}$ Indeed, a reduced gene and protein expression of CaSR is found in parathyroid adenomas. ${ }^{26}$ An allelic loss at the locus of the CASR gene has even been identified in $10 \%$ of parathyroid adenomas in one study, ${ }^{27}$ but not confirmed in another. ${ }^{28}$ It has been suggested that $\mathrm{FHH} 1$ could predispose to the development of parathyroid adenomas. ${ }^{29}$

Finally, we did not find any correlation between genotype and phenotype, but only 10 mutations were reported in two or more patients. Significant inter-mutation variations were found with regard to the femoral and lumbar Z score, and plasma calcium and PTH levels in the Danish series. ${ }^{3,30}$ However, Vargas-Poussou et al ${ }^{7}$ found similar phenotypes regardless of the protein domain affected by the mutation.

\subsection{Strength and limitations of the study}

The strength of this study is the high number of patients enrolled. It is one of the largest cohorts to date and is probably representative of adult FHH1 patients. Data were collected from each patient's record.

The limitations of the study are due to its retrospective design given the rarity of the pathology. Some French centres did not respond to our data request, and by consequence, the 45 patients who were followed in these centres were excluded. Moreover, 39 patients were excluded due to insufficient data in the medical files. Data were collected in 80 patients (48\% of the initial population) so that it remains the largest French cohort of $\mathrm{FHH} 1$.

No homogeneous protocol was available for data collection, notably for the blood and urine analyses. Some data were sparse because not all parameters were investigated in each patient. In terms of laboratory data, blood and urine samples were analysed in each centre using different kits. Laboratory measurements were not standardized regarding interfering medications, time of the day or dietary intake. Nevertheless, these measurements reflect clinical practice.

Moreover, some CASR mutations have not been yet described and identified in terms of function. However, ACMG classification is consistent with pathogenicity. The classification of these missense variants as likely pathogenic (class 4 ) results from the combination of two or three moderate criteria and two supporting criteria. The distribution of the mutations, primarily in the extracellular domain of the receptor and mainly missense, is similar to that described in other studies. ${ }^{7,31}$

\section{5 | CONCLUSION}

The data presented here show that an atypical characteristic has been found in one-third of $\mathrm{FHH1}$ patients, such as hypercalciuria, 
TAB LE 4 Mutation description of our study population

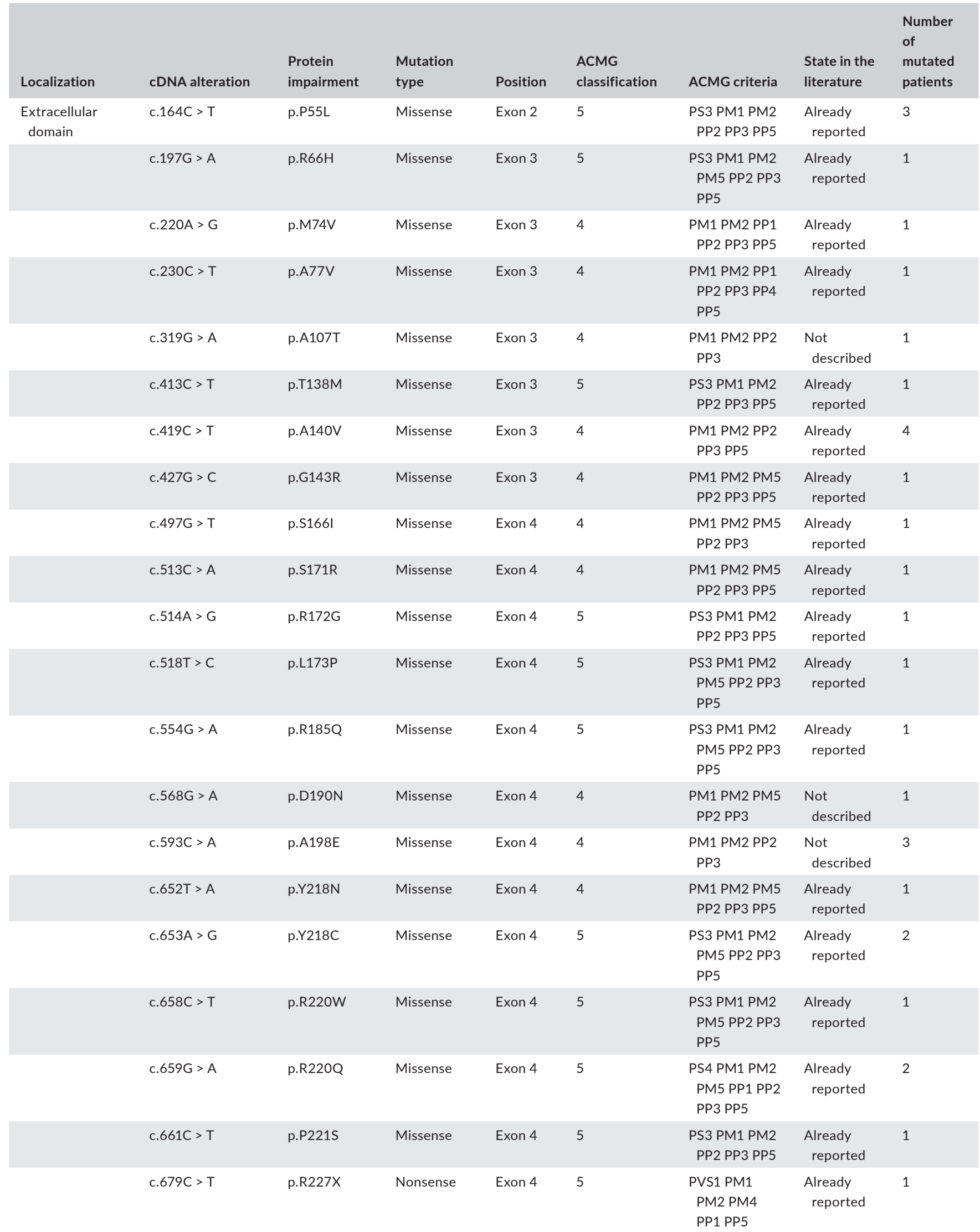


TABLE 4 (Continued)

\begin{tabular}{|c|c|c|c|c|c|c|c|c|}
\hline \multirow[t]{10}{*}{ Localization } & cDNA alteration & $\begin{array}{l}\text { Protein } \\
\text { impairment }\end{array}$ & $\begin{array}{l}\text { Mutation } \\
\text { type }\end{array}$ & Position & $\begin{array}{l}\text { ACMG } \\
\text { classification }\end{array}$ & ACMG criteria & $\begin{array}{l}\text { State in the } \\
\text { literature }\end{array}$ & $\begin{array}{l}\text { Number } \\
\text { of } \\
\text { mutated } \\
\text { patients }\end{array}$ \\
\hline & c. $893 \mathrm{C}>\mathrm{T}$ & p.A298V & Missense & Exon 4 & 4 & $\begin{array}{l}\text { PM1 PM2 PM5 } \\
\text { PP2 PP3 }\end{array}$ & $\begin{array}{l}\text { Not } \\
\text { described }\end{array}$ & 1 \\
\hline & c. $1244 \mathrm{G}>\mathrm{A}$ & p.R415Q & Missense & Exon 4 & 4 & $\begin{array}{l}\text { PM1 PM2 PP2 } \\
\text { PP3 }\end{array}$ & $\begin{array}{l}\text { Not } \\
\text { described }\end{array}$ & 1 \\
\hline & c. $1377+1 G>T$ & p.? & Splicing & Intron 4 & 5 & $\begin{array}{l}\text { PVS1 PM2 PP2 } \\
\text { PP3 }\end{array}$ & $\begin{array}{l}\text { Not } \\
\text { described }\end{array}$ & 1 \\
\hline & c. $1393 C>T$ & p.R465W & Missense & Exon 5 & 5 & $\begin{array}{l}\text { PS3 PM1 PM2 } \\
\text { PM5 PP2 PP3 } \\
\text { PP5 }\end{array}$ & $\begin{array}{l}\text { Already } \\
\text { reported }\end{array}$ & 3 \\
\hline & c. $1608+3 A>C$ & p.? & Splicing & Intron 5 & 4 & PM1 PM2 PP3 & $\begin{array}{l}\text { Already } \\
\text { reported }\end{array}$ & 1 \\
\hline & c. $1609-1 \mathrm{G}>\mathrm{T}$ & p.? & Splicing & Intron 5 & 5 & $\begin{array}{r}\text { PVS1 PM1 } \\
\text { PM2 PP3 }\end{array}$ & $\begin{array}{l}\text { Not } \\
\text { described }\end{array}$ & 1 \\
\hline & c. $1645 \mathrm{G}>\mathrm{A}$ & p.G549R & Missense & Exon 6 & 5 & $\begin{array}{l}\text { PS3 PS4 PM1 } \\
\text { PM2 PP2 PP3 } \\
\text { PP5 }\end{array}$ & $\begin{array}{l}\text { Already } \\
\text { reported }\end{array}$ & 1 \\
\hline & c. $1661 \mathrm{~T}>\mathrm{A}$ & p. $1554 \mathrm{~N}$ & Missense & Exon 6 & 5 & $\begin{array}{c}\text { PS4 PM1 PM2 } \\
\text { PP2 PP3PP5 }\end{array}$ & $\begin{array}{l}\text { Already } \\
\text { reported }\end{array}$ & 1 \\
\hline & c. $1664 \mathrm{~T}>\mathrm{C}$ & p. $1555 \mathrm{~T}$ & Missense & Exon 6 & 4 & $\begin{array}{l}\text { PM1, PM2, } \\
\text { PP2, PP3, } \\
\text { PP5 }\end{array}$ & $\begin{array}{l}\text { Already } \\
\text { reported }\end{array}$ & 1 \\
\hline \multirow[t]{8}{*}{$\begin{array}{l}\text { Transmembrane } \\
\text { domain }\end{array}$} & c. $1901 \mathrm{~T}>\mathrm{C}$ & p.F634S & Missense & Exon 7 & 4 & $\begin{array}{l}\text { PM1 PM2 PP1 } \\
\text { PP2 PP3 }\end{array}$ & $\begin{array}{l}\text { Already } \\
\text { reported }\end{array}$ & 1 \\
\hline & c. $1919 \mathrm{C}>\mathrm{T}$ & p.T640I & Missense & Exon 7 & 4 & $\begin{array}{l}\text { PM1 PM2 PP2 } \\
\text { PP4 PP5 }\end{array}$ & $\begin{array}{l}\text { Already } \\
\text { reported }\end{array}$ & 1 \\
\hline & c. $1942 C>T$ & p.R648X & Nonsense & Exon 7 & 5 & $\begin{array}{l}\text { PVS1, PM1, } \\
\text { PM2, PP5 }\end{array}$ & $\begin{array}{l}\text { Already } \\
\text { reported }\end{array}$ & 2 \\
\hline & $\begin{array}{l}\text { c.1963_1965 } \\
\text { delCTC }\end{array}$ & p.L655del & Deletion & Exon 7 & 4 & $\begin{array}{l}\text { PM1 PM2 PM4 } \\
\text { PP3 PP5 }\end{array}$ & $\begin{array}{l}\text { Already } \\
\text { reported }\end{array}$ & 1 \\
\hline & c. $2008 \mathrm{G}>\mathrm{A}$ & p.G670R & Missense & Exon 7 & 5 & $\begin{array}{l}\text { PS3 PM1 PM2 } \\
\text { PM5 PP2 PP3 } \\
\text { PP5 }\end{array}$ & $\begin{array}{l}\text { Already } \\
\text { reported }\end{array}$ & 1 \\
\hline & c2029dup & $\begin{array}{l}\text { p.Cys677 } \\
\text { Leufs*31 }\end{array}$ & Duplication & Exon 7 & 5 & $\begin{array}{l}\text { PVS1 PM1 } \\
\text { PM2 PM4 }\end{array}$ & $\begin{array}{l}\text { Not } \\
\text { described }\end{array}$ & 2 \\
\hline & c. $2038 \mathrm{C}>\mathrm{A}$ & p.R680S & Missense & Exon 7 & 4 & $\begin{array}{l}\text { PM1 PM2 PM5 } \\
\text { PP2 PP3 }\end{array}$ & $\begin{array}{l}\text { Not } \\
\text { described }\end{array}$ & 1 \\
\hline & c. $2038 \mathrm{C}>\mathrm{T}$ & p.R680C & Missense & Exon 7 & 5 & $\begin{array}{l}\text { PS3 PM1 PM2 } \\
\text { PM5 PP2 PP3 } \\
\text { PP5 }\end{array}$ & $\begin{array}{l}\text { Already } \\
\text { reported }\end{array}$ & 1 \\
\hline
\end{tabular}




\begin{tabular}{|c|c|c|c|c|c|c|c|c|}
\hline Localization & cDNA alteration & $\begin{array}{l}\text { Protein } \\
\text { impairment }\end{array}$ & $\begin{array}{l}\text { Mutation } \\
\text { type }\end{array}$ & Position & $\begin{array}{l}\text { ACMG } \\
\text { classification }\end{array}$ & ACMG criteria & $\begin{array}{l}\text { State in the } \\
\text { literature }\end{array}$ & $\begin{array}{l}\text { Number } \\
\text { of } \\
\text { mutated } \\
\text { patients }\end{array}$ \\
\hline & c. $2039 \mathrm{G}>\mathrm{A}$ & p.R680H & Missense & Exon 7 & 5 & $\begin{array}{l}\text { PS3 PM1 PM2 } \\
\text { PM5 PP2 PP3 } \\
\text { PP5 }\end{array}$ & $\begin{array}{l}\text { Already } \\
\text { reported }\end{array}$ & 2 \\
\hline & c. $2072 \mathrm{G}>\mathrm{A}$ & p.C691Y & Missense & Exon 7 & 4 & $\begin{array}{l}\text { PM1 PM2 PP2 } \\
\text { PP3 }\end{array}$ & $\begin{array}{l}\text { Not } \\
\text { described }\end{array}$ & 1 \\
\hline & c. $2089 \mathrm{G}>\mathrm{A}$ & p.V697M & Missense & Exon 7 & 5 & $\begin{array}{r}\text { PS3 PM1 PM2 } \\
\text { PP2 PP3 PP5 }\end{array}$ & $\begin{array}{l}\text { Already } \\
\text { reported }\end{array}$ & 1 \\
\hline & c.2083_2106dup & $\begin{array}{l}\text { p.(Ile695_ } \\
\text { Val702dup) }\end{array}$ & $\begin{array}{l}\text { Duplication } \\
\text { in-frame }\end{array}$ & Exon 7 & 4 & $\begin{array}{l}\text { PM1 PM2 } \\
\text { PM4 PP3 }\end{array}$ & $\begin{array}{l}\text { Not } \\
\text { described }\end{array}$ & 1 \\
\hline & c. $2203 C>A$ & p.Q735K & Missense & Exon 7 & 4 & $\begin{array}{l}\text { PM1 PM2 PP2 } \\
\text { PP3 }\end{array}$ & $\begin{array}{l}\text { Not } \\
\text { described }\end{array}$ & 1 \\
\hline & c. $2243 \mathrm{C}>\mathrm{A}$ & p.P748H & Missense & Exon 7 & 4 & $\begin{array}{c}\text { PM1 PM2 PM5 } \\
\text { PP2 PP3 PP5 }\end{array}$ & $\begin{array}{l}\text { Already } \\
\text { reported }\end{array}$ & 1 \\
\hline & c. $2243 C>G$ & p.P748R & Missense & Exon 7 & 5 & $\begin{array}{r}\text { PS3 PM1 PM2 } \\
\text { PP2 PP3 PP5 }\end{array}$ & $\begin{array}{l}\text { Already } \\
\text { reported }\end{array}$ & 1 \\
\hline & c. $2386 \mathrm{~A}>\mathrm{T}$ & p.K796X & Nonsense & Exon 7 & 5 & $\begin{array}{r}\text { PVS1 PM1 } \\
\text { PM2 PP5 }\end{array}$ & $\begin{array}{l}\text { Already } \\
\text { reported }\end{array}$ & 1 \\
\hline & c. $2401 T>C$ & p.F801L & Missense & Exon 7 & 4 & $\begin{array}{l}\text { PM1 PM2 PP2 } \\
\text { PP3 PP5 }\end{array}$ & $\begin{array}{l}\text { Already } \\
\text { reported }\end{array}$ & 1 \\
\hline & c. $2467 C>T$ & p.P823S & Missense & Exon 7 & 4 & $\begin{array}{l}\text { PM1 PM2 PP2 } \\
\text { PP3 }\end{array}$ & $\begin{array}{l}\text { Not } \\
\text { described }\end{array}$ & 1 \\
\hline & c. $2479 A>G$ & p.S827G & Missense & Exon 7 & 4 & $\begin{array}{l}\text { PM1 PM2 PM5 } \\
\text { PP2 PP3 }\end{array}$ & $\begin{array}{l}\text { Not } \\
\text { described }\end{array}$ & 1 \\
\hline & c. $2579 \mathrm{~T}>\mathrm{G}$ & p. $1860 \mathrm{~S}$ & Missense & Exon 7 & 4 & $\begin{array}{l}\text { PM1 PM2 PP2 } \\
\text { PP3 PP5 }\end{array}$ & $\begin{array}{l}\text { Already } \\
\text { reported }\end{array}$ & 1 \\
\hline
\end{tabular}

Note: PVS, very strong evidence of pathogenicity; PVS1, null variant (nonsense, frameshift, canonical +/-1 or 2 splice sites, initiation codon, single or multi-exon deletion) in a gene where loss of function is a known mechanism of disease; PS, strong evidence of pathogenicity; PS1, same amino acid change as a previously established pathogenic variant regardless of nucleotide change; PS3, well-established in vitro or in vivo functional studies supportive of a damaging effect on the gene or gene product; PS4, the prevalence of the variant in affected individuals is significantly increased compared to the prevalence in controls; PM, moderate evidence of pathogenicity; PM1, Located in a mutational hot spot and/or critical and wellestablished functional domain without benign variation; PM2, absent from controls (or at extremely low frequency if recessive) in gnomAD database; PM3, detected in trans with a pathogenic variant (the phase was determined); PM4, protein length changes due to in-frame deletions/insertions in a nonrepeat region or stop-loss variants; PM5, Novel missense change at an amino acid residue where a different missense change determined to be pathogenic has been seen before; PP, supporting evidence of pathogenicity; PP1, Co-segregation with disease in multiple affected family members in a gene definitively known to cause the disease; PP2, Missense variant in a gene that has a low rate of benign missense variation and in which missense variants are a common mechanism of disease; PP3, Multiple lines of computational evidence support a deleterious effect on the gene or gene product; PP5, Reputable source recently reports variant as pathogenic but the evidence is not available to the laboratory to perform an independent evaluation. 
elevated PTH plasma levels, presence of kidney stones or osteoporotic bone fracture, evidence of parathyroid adenoma on a neck ultrasonography or MIBI scintigraphy, or surgically removed parathyroid adenoma. CCCR is not sufficient to accurately distinguish between FHH from PHPT. Diagnostic criteria must be improved in order to identify $\mathrm{FHH} 1$ patients more effectively. Moreover, the presence of parathyroid adenomas does not appear to be sheer coincidence. Indeed, $\mathrm{FHH}$ patients may be more prone to developing parathyroid adenomas so that a follow-up of these patients may be useful. The classical therapeutic abstention is not necessarily warranted in all FHH1 patients. Finally, no relationship between genotype and phenotype could be identified in this large cohort of $\mathrm{FHH}$ type 1 patients.

\section{ACKNOWLEDGEMENTS}

This work was supported by the French National Network for Rare Disorders of Calcium and Phosphate Metabolism. We are very grateful to the patients and their physicians in every unit who agreed to participate (Pr Groussin (Paris), Dr Brottier-Mancini (La Rochelle), Pr Murat (Nantes), Pr Archambeaud (Limoges), Pr Estour (Saint Etienne), Pr Fenichel (Nices), Dr Biley (Cahors), Pr Borson-Chazot (Lyon), Dr Quefeullou (Cherbourg), Dr Vincent-Dejean (Chartres), Dr Vagneur (Aubagne), Pr Huet (Dijon), Dr Salenave (Kremlin-Bicètre), Pr Touraine (Paris), Dr Ogor (Pont L'abbé), Pr Guggenbuhl and Dr Frouget (Rennes), Dr Jacquin (Saint Nazaire), Dr Javier Moder (Strasbourg), Dr Verier-Mine (Valenciennes)

\section{CONFLICT OF INTEREST}

There is no conflict of interest to potentially prejudice the impartiality of the research reported.

\section{DATA AVAILABILITY STATEMENT}

The data that support the findings of this study are available from the corresponding author upon reasonable request.

\section{ORCID}

Céline Mouly iD https://orcid.org/0000-0003-4393-5351 Rosa Vargas-Poussou iD https://orcid.org/0000-0002-4169-0680 Antoine Tabarin iD https://orcid.org/0000-0003-1231-3306 Philippe Caron (iD https://orcid.org/0000-0001-5391-7582 Delphine Vezzosi (iD https://orcid.org/0000-0002-6600-4552

\section{REFERENCES}

1. Foley TP, Harrison HC, Arnaud CD, Harrison HE. Familial benign hypercalcemia. J Pediatr. 1972;81(6):1060-1067.

2. Chou $\mathrm{YH}$, Pollak MR, Brandi ML, et al. Mutations in the human $\mathrm{Ca}(2+)$-sensing-receptor gene that cause familial hypocalciuric hypercalcemia. Am J Hum Genet. 1995;56(5):1075-1079.

3. Christensen SE, Nissen PH, Vestergaard P, et al. Skeletal consequences of familial hypocalciuric hypercalcaemia vs. primary hyperparathyroidism. Clin Endocrinol (Oxf). 2009;71(6):798-807.

4. Bertocchio J-P, Tafflet M, Koumakis E, et al. Pro-FHH: A Risk Equation to Facilitate the Diagnosis of Parathyroid-Related Hypercalcemia. J Clin Endocrinol Metab. 2018;103(7):2534-2542.

5. Simonds WF, James-Newton LA, Agarwal SK, et al. Familial isolated hyperparathyroidism: clinical and genetic characteristics of $36 \mathrm{kin}-$ dreds. Medicine (Baltimore). 2002;81(1):1-26.
6. Volpe A, Guerriero A, Marchetta A, Caramaschi P, Furlani L. Familial hypocalciuric hypercalcemia revealed by chondrocalcinosis. Jt Bone Spine Rev Rhum. 2009;76(6):708-710.

7. Vargas-Poussou R, Mansour-Hendili L, Baron S, et al. Familial hypocalciuric hypercalcemia types 1 and 3 and primary hyperparathyroidism: similarities and differences. J Clin Endocrinol Metab. 2016;101(5):2185-2195.

8. Lia-Baldini A-S, Magdelaine C, Nizou A, et al. Two novel mutations of the calcium-sensing receptor gene affecting the same amino acid position lead to opposite phenotypes and reveal the importance of p. N802 on receptor activity. Eur J Endocrinol. 2013;168(2):K27-K34.

9. Richards S, Aziz N, Bale S, et al. Standards and guidelines for the interpretation of sequence variants: a joint consensus recommendation of the American College of Medical Genetics and Genomics and the Association for Molecular Pathology. Genet Med Off J Am Coll Med Genet. 2015;17(5):405-424.

10. Marx SJ, Stock JL, Attie MF, et al. Familial hypocalciuric hypercalcemia: recognition among patients referred after unsuccessful parathyroid exploration. Ann Intern Med. 1980;92(3):351-356.

11. Gunn IR, Wallace JR. Urine calcium and serum ionized calcium, total calcium and parathyroid hormone concentrations in the diagnosis of primary hyperparathyroidism and familial benign hypercalcaemia. Ann Clin Biochem. 1992;29(Pt 1):52-58.

12. Marx SJ, Attie MF, Levine MA, Spiegel AM, Downs RW, Lasker RD. The hypocalciuric or benign variant of familial hypercalcemia: clinical and biochemical features in fifteen kindreds. Medicine (Baltimore). 1981;60(6):397-412.

13. Marx SJ, Spiegel AM, Brown EM, et al. Divalent cation metabolism. Familial hypocalciuric hypercalcemia versus typical primary hyperparathyroidism. Am J Med. 1978;65(2):235-242.

14. Guarnieri V, Canaff L, Yun FHJ, et al. Calcium-sensing receptor (CASR) mutations in hypercalcemic states: studies from a single endocrine clinic over three years. J Clin Endocrinol Metab. 2010;95(4):1819-1829.

15. Rajala MM, Klee GG, Heath H. Calcium regulation of parathyroid and $\mathrm{C}$ cell function in familial benign hypercalcemia. $J$ Bone Miner Res Off J Am Soc Bone Miner Res. 1991;6(2):117-124.

16. Christensen SE, Nissen PH, Vestergaard P, Heickendorff L, Brixen $\mathrm{K}$, Mosekilde L. Discriminative power of three indices of renal calcium excretion for the distinction between familial hypocalciuric hypercalcaemia and primary hyperparathyroidism: a follow-up study on methods. Clin Endocrinol (Oxf). 2008;69(5):713-720.

17. Frank-Raue K, Leidig-Bruckner G, Haag C, et al. Inactivating calcium-sensing receptor mutations in patients with primary hyperparathyroidism. Clin Endocrinol (Oxf). 2011;75(1):50-55.

18. Egan AM, Ryan J, Aziz MA, O'Dwyer TP, Byrne MM. Primary hyperparathyroidism in a patient with familial hypocalciuric hypercalcaemia due to a novel mutation in the calcium-sensing receptor gene. $J$ Bone Miner Metab. 2013;31(4):477-480.

19. Yabuta T, Miyauchi A, Inoue H, Yoshida H, Hirokawa M, Amino N. A patient with primary hyperparathyroidism associated with familial hypocalciuric hypercalcemia induced by a novel germline CaSR gene mutation. Asian J Surg Asian Surg Assoc. 2009;32(2):118-122.

20. Burski K, Torjussen B, Paulsen AQ, Boman H, Bollerslev J. Parathyroid adenoma in a subject with familial hypocalciuric hypercalcemia: coincidence or causality? J Clin Endocrinol Metab. 2002;87(3):1015-1016.

21. Brachet C, Boros E, Tenoutasse S, et al. Association of parathyroid adenoma and familial hypocalciuric hypercalcaemia in a teenager. Eur J Endocrinol Eur Fed Endocr Soc. 2009;161(1):207-210.

22. Forde HE, Hill AD, Smith D. Parathyroid adenoma in a patient with familial hypocalciuric hypercalcaemia. BMJ Case Rep. 2014;2014:bcr2014206473-bcr2014206473.

23. Eldeiry LS, Ruan DT, Brown EM, Gaglia JL, Garber JR. Primary hyperparathyroidism and familial hypocalciuric hypercalcemia: relationships and clinical implications. Endocr Pract Off J Am Coll Endocrinol Am Assoc Clin Endocrinol. 2012;18(3):412-417. 
24. Ho C, Conner DA, Pollak MR, et al. A mouse model of human familial hypocalciuric hypercalcemia and neonatal severe hyperparathyroidism. Nat Genet. 1995;11(4):389-394.

25. Corbetta S, Lania A, Filopanti M, Vicentini L, Ballaré E, Spada A. Mitogen-activated protein kinase cascade in human normal and tumoral parathyroid cells. J Clin Endocrinol Metab. 2002;87(5):2201-2205.

26. Cetani F, Picone A, Cerrai P, et al. Parathyroid expression of calcium-sensing receptor protein and in vivo parathyroid hormone- $\mathrm{Ca}(2+)$ set-point in patients with primary hyperparathyroidism. J Clin Endocrinol Metab. 2000;85(12):4789-4794.

27. Thompson DB, Samowitz WS, Odelberg S, Davis RK, Szabo J, Heath $H$. Genetic abnormalities in sporadic parathyroid adenomas: loss of heterozygosity for chromosome $3 q$ markers flanking the calcium receptor locus. J Clin Endocrinol Metab. 1995;80(11):3377-3380.

28. Cetani F, Pinchera A, Pardi E, et al. No evidence for mutations in the calcium-sensing receptor gene in sporadic parathyroid adenomas. $J$ Bone Miner Res Off J Am Soc Bone Miner Res. 1999;14(6):878-882.

29. Szabo E, Carling T, Hessman O, Rastad J. Loss of heterozygosity in parathyroid glands of familial hypercalcemia with hypercalciuria and point mutation in calcium receptor. $J$ Clin Endocrinol Metab. 2002;87(8):3961-3965.
30. Christensen SE, Nissen PH, Vestergaard P, et al. Plasma 25-hydroxyvitamin D, 1,25-dihydroxyvitamin D, and parathyroid hormone in familial hypocalciuric hypercalcemia and primary hyperparathyroidism. Eur J Endocrinol Eur Fed Endocr Soc. 2008;159(6):719-727.

31. Hannan FM, Nesbit MA, Christie PT, et al. A homozygous inactivating calcium-sensing receptor mutation, Pro339Thr, is associated with isolated primary hyperparathyroidism: correlation between location of mutations and severity of hypercalcaemia. Clin Endocrinol (Oxf). 2010;73(6):715-722.

How to cite this article: Mouly C, Vargas-Poussou R, Lienhardt A, et al; for the Reference Centre for Rare Diseases of Calcium, Phosphate Metabolism. Clinical characteristics of familial hypocalciuric hypercalcaemia type 1: A multicentre study of 77 adult patients. Clin Endocrinol (Oxf).

2020;93:248-260. https://doi.org/10.1111/cen.14211 